\title{
PENGEMBANGAN MODUL PEMBELAJARAN IPA BIOLOGI BERBASIS INKUIRI PADA MATERI INTERAKSI ANTAR MAKHLUK HIDUP DENGAN LINGKUNGANNYA
}

\author{
M. Khoirudin \\ Universitas Nahdlatul Ulama Lampung \\ E-mail: iru1_tpg13@yahoo.com
}

\begin{abstract}
Module is designed learning materials systematically based on specific of curriculum and packed in the smallest unit of learning and enable the students to learn dependent certain time. The an of the research: To describe the learning model that has been developed at this time, develop learning module Inquiry-Based Science Biology Matters Interaction between the organism with the environment, describe the inquiry-based module that has been developed, reveal the advantage and disadvantage of learning module that has been developed. The research used plan of research and development. The research data obtained in the analysis of descriptive percentages. The resulting expert testing design is $84,84 \%$, expert testing material $88,47 \%$. This means the module of science biology was developed is "Good" used in learning. The conclusion of this research is module Inquiry-based Science Biology on the theme Interaction between the organism with the Environment that developed "Good" is use din teaching students of SMP/MTs.
\end{abstract}

Kata Kunci: modul, IPA Biologi. interaksi antar makhluk hidup

Keterbatasan waktu di dalam kelas dapat ditutupi dengan proses pembelajaran yang dilakukan secara mandiri oleh masing-masing siswa. Belajar secara mandiri, disamping belajar di dalam kelas, dapat memenuhi tujuan pembelajaran. Siswa dapat memahami materi dengan cepat dengan kemampuan masing-masing. Dengan demikian diperlukan lebih dari buku untuk dapat membimbing siswa untuk menjadi lebih aktif belajar secara mandiri. Berdasarkan hasil wawancara dengan guru IPA di MTs Bandar Agung, modul sudah digunakan sebagai salah satu bahan belajar siswa. Namun penggunaannya masih seperti buku, karena hanya terdapat penjabaran meteri serta paket soal evaluasi. Modul seperti ini kurang dapat digunakan sebagai bahan belajar mandiri siswa, karena dipandang siswa kurang menarik. Untuk itu perlu adanya bahan ajar yang dapat digunakan sebagai sarana belajar mandiri oleh siswa.
Bahan ajar penting digunakan dalam pembelajaran, karena bahan ajar berfungsi sebagai alat bantu dalam kegiatan pembelajaran. Dharma (2008: 3) mengemukakan bahwa modul merupakan bahan ajar cetak yang dirancang untuk dapat dipelajari secara mandiri oleh peserta didik. Modul disebut juga media untuk belajar mandiri karena di dalamnya telah dilengkapi petunjuk untuk belajar sendiri. Artinya, pembaca dapat melakukan kegiatan belajar tanpa kehadiran pengajar secara langsung. Bahasa, pola, dan sifat kelengkapan lainnya yang terdapat dalam modul ini diatur sehingga ia seolah-olah merupakan "bahasa pengajar" atau bahasa guru yang sedang memberikan pengajaran kepada murid-muridnya. Maka dari itulah, media ini sering disebut bahan instruksional mandiri. Penelitian yang relevan telah dilakukan oleh Novana (2014: 112) tentang pengembangan modul inkuiri 
terbimbing berbasis potensi lokal menunjukkan bahwa Modul Pembelajaran dapat dipakai secara individual ataupun dipakai sebagai media pembelajaran yang digunakan guru.

Menurut Russel (dalam Sumiati, 2008: 114) modul merupakan suatu paket belajar mengajar berkenaan dengan satu unit meteri pembelajaran. Dengan modul siswa dapat mencapai taraf finising (tuntas) dengan belajar secara individual. Siswa tidak dapat melanjutkan ke suatu unit pelajaran berikutnya sebelum mencapai taraf tuntas.

Dari uraian di atas dapat dikemukakan bahwa modul adalah bahan belajar yang dirancang secara sistematis berdasarkan kurikulum tertentu dan dikemas dalam satuan pembelajaran terkecil dan memungkinkan dipelajari sis wa secara mandiri dalam waktu tertentu, sehingga siswa dapat belajar sesuai dengan kecepatan masing-masing, tanpa terikat oleh waktu, tempat, dan hal-hal lain di luar dirinya sendiri.

Ilmu Pengetahuan Alam adalah ilmu yang mempelajari gejala-gejala alam yang dapat dirumuskan kebenarannya secara empiris. Purwasari (2013: 536) mengemukakan bahawa "pembelajaran IPA memiliki peranan yang sangat penting dalam meningkatkan kualitas pendidikan serta memfokuskan pada peningkatan pengetahuan siswa tentang diri sendiri dan alam sekitarnya".

Pembelajaran dengan menggunakan model inkuiri yaitu pembelajaran yang berpusat pada siswa. Hendarwati (2013: 62) menyatakan inkuiri adalah suatu proses pembelajaran yang diharapkan dapat mengarahkan siswa untuk mengidentifikasi, mengajukan pertanyaan yang berkaitan dengan masalah, merumuskan hipotesis dan melakukan pengamatan untuk menjawab pertanyaan-pertanyaan dalam proses pembelajaran ini siswa lebih banyak belajar sendiri, mengembangkan kreativitas dalam memecahkan masalah.

\section{METODE}

Jenis penelitian ini adalah Research and Development yang bertujuan untuk mengembangkan modul pembelajaran berbasis inkuiri pada materi interaksi antar makhluk hidup dengan lingkungannya. Penelitian dan pengembangan ini dikemukakan oleh Thiagarajan (dalam Trianto 2014: 94). Adapun langkahlangkahnya sebagai berikut: 1) Pendefinisian, 2) Perancangan, 3) Pengembangan (validasi, uji coba kecil, dan uji coba besar), 4) Penyebaran. Subjek penelitian untuk uji coba produk yang dikembangkan dalam penelitian ini adalah siswa kelas VII MTs Bandar Agung semester 2 Tahun ajaran 2014/2015. Instrument penelitian yang digunakan untuk mengumpulkan data dalam uji coba berupa Angket/kuesioner. Kuesioner sebagai lembar penilaian produk digunakan untuk mendapatkan data tentang kelayakan modul hasil pengembangan. Dalam menganalisis angket menggunakan rumus Sudjana (dalam Elvinawati 2008: 19).

$$
\begin{array}{ll}
\bar{x}: \frac{\sum x}{N} \mathrm{x} & 100 \% \\
\text { Keterangan: } \\
\bar{x} \quad: \text { Skor rata-rata } \\
\sum x \quad \text { : Jumlah skor } \\
\mathrm{N} & : \text { Jumlah } \\
& \text { responden }
\end{array}
$$

Setelah penilaian angket selesai dihitung persentasenya, maka tahap selanjutnya yaitu menafsirkan angka, Setelah penilaian angket selesai dihitung persentasenya, maka tahap selanjutnya yaitu menafsirkan angka yang didapat dari hasil perhitungan, hal ini bertujuan untuk mengetahui tingkat 
kelayakan dan keterbacaan modul yang menggunakan cara penafsiran Sudjana telah dikembangkan. Penilaian ini (dalam Hidayah 2014:53)

\begin{tabular}{c|c|c}
\hline $\begin{array}{c}\text { Tingkat } \\
\text { Pencapaian }\end{array}$ & Krite ria & Keterangan \\
\hline $90 \% \leq \mathrm{p} \leq 100 \%$ & Sangat Baik & Tidak perlu direvisi \\
\hline $75 \% \leq \mathrm{p}<90 \%$ & Baik & Tidak perlu direvisi \\
\hline $65 \% \leq \mathrm{p}<75 \%$ & Cukup & Direvisi \\
\hline $55 \% \leq \mathrm{p}<65 \%$ & Kurang & Direvisi \\
\hline $0 \leq \mathrm{p} \leq 55 \%$ & Sangat Kurang & Direvisi \\
\hline
\end{tabular}

\section{HASIL}

a. Data Hasil Pengujian Desain Tampilan Modul

Data hasil pengujian kelayakan tampilan desain Modul ini merupakan rekapitulasi penilaian dari 3 ahli media pembelajaran. Hasil tersebut direkapitulasikan menjadi satu yang dapat disajikan dalam tabel 1.

Tabel 1. Hasil Rekapitulasi Data Pengujian oleh Ahli Media Pembelajaran tentang Tampilan Desain Modul.

\begin{tabular}{l|l|c|c|c}
\hline \multirow{2}{*}{ No. } & \multicolumn{1}{|c}{ Pernyataan } & \multicolumn{3}{c}{ Skor Ahli } \\
\cline { 3 - 5 } & \multicolumn{1}{|c}{ Ahli 1 } & Ahli 2 & Ahli 3 \\
\hline 1. & Caver Modul terlihat jelas, dan menarik. & 3 & 4 & 4 \\
\hline 2. & $\begin{array}{l}\text { Gambar sudah sesuai dengan materi yang } \\
\text { disampaikan }\end{array}$ & 4 & 4 & 5 \\
\hline 3. & $\begin{array}{l}\text { Penempatan kolom informasi atau tugas dalam } \\
\text { Modul. }\end{array}$ & 4 & 4 & 4 \\
\hline 4. & $\begin{array}{l}\text { Pemberian kata motivasi sesuai dengan kondisi } \\
\text { dan keadaan peserta didik. }\end{array}$ & 4 & 5 & 5 \\
\hline 5. & $\begin{array}{l}\text { Ukuran dan jenis huruf pada Modul terlihat } \\
\text { jelas dan konsisten }\end{array}$ & 5 & 4 & 4 \\
\hline 6. & $\begin{array}{l}\text { Tampilan Modul tiap halaman menarik dan } \\
\text { konsisten }\end{array}$ & 4 & 4 & 4 \\
\hline 7. & $\begin{array}{l}\text { Ukuran kertas Modul sudah sesuai standar } \\
\text { yang digunakan yaitu A4 }\end{array}$ & 5 & 4 & 5 \\
\hline 8. & $\begin{array}{l}\text { Pemilihan kata dari setiap informasi mudah } \\
\text { dipahami sesuai dengan perkembangan peserta } \\
\text { didik. }\end{array}$ & 4 & 4 & 4 \\
\hline 9. & $\begin{array}{l}\text { Pemilihan kata yang digunakan tidak } \\
\text { mengandung makna ambigu. }\end{array}$ & 4 & 4 & 4 \\
\hline 10. & $\begin{array}{l}\text { Pemilihan gambar menarik dan sesuai dengan } \\
\text { materi yang disampaikan. }\end{array}$ & 5 & 4 & 4 \\
\hline 11. & $\begin{array}{l}\text { Penggunaan warna pada Modul baik pada } \\
\text { tulisan maupun gambar terlihat jelas, sehingga } \\
\text { menjadikan Modul terlihat indah dan menarik }\end{array}$ & 4 & 4 & 5 \\
\hline
\end{tabular}


M. KHOIRUDIN， PENGEMBANGAN MODUL PEMBELAJARAN....

\begin{tabular}{l|c|c|c}
\hline Jumlah & 46 & 45 & 48 \\
\hline Rata-rata & 4,1 & 4,09 & 4,3 \\
\hline
\end{tabular}

b. Data Hasil Pengujian Ahli Materi dalam Modul

Tabe1 2. Rekapitulasi Data Hasil Pengujian Ahli Materi Pembelajaran dalam Modul

\begin{tabular}{|c|c|c|c|c|}
\hline \multirow{2}{*}{ No. } & \multirow{2}{*}{ Pernyataan } & \multicolumn{3}{|c|}{ Skor Ahli } \\
\hline & & Ahli 1 & Ahli 2 & Ahli 3 \\
\hline 1. & $\begin{array}{l}\text { Materi yang dijelaskan sesuai dengan } \\
\text { Kompetensi Inti (KI) dan Kompetensi Dasar } \\
(\mathrm{KD}) \text {. }\end{array}$ & 4 & 5 & 4 \\
\hline 2. & $\begin{array}{l}\text { Materi yang dijelaskan cukup dalam, dan } \\
\text { mampu memberikan informasi yang baik } \\
\text { kepada peserta didik tentang interaksi antar } \\
\text { makhluk hidup. }\end{array}$ & 4 & 5 & 5 \\
\hline 3. & $\begin{array}{l}\text { Materi yang disampaikan sudah baik, dan } \\
\text { terkini. }\end{array}$ & 4 & 5 & 4 \\
\hline 4. & Sistematika penyusunan materi berurutan. & 4 & 5 & 4 \\
\hline 5. & $\begin{array}{l}\text { Penggunaan simbol dan istilah dalam materi } \\
\text { konsisten dan tepat. }\end{array}$ & 5 & 5 & 5 \\
\hline 6. & $\begin{array}{l}\text { Penyusunan kalimat dalam Modul baik sesuai } \\
\text { dengan Ejaan Yang Disempurnakan (EYD). }\end{array}$ & 4 & 5 & 4 \\
\hline 7. & $\begin{array}{l}\text { Isi Modul komunikatif, mampu mengajak } \\
\text { peserta didik untuk aktif, dan komunikasi dua } \\
\text { arah terjalin. }\end{array}$ & 4 & 5 & 4 \\
\hline 8. & $\begin{array}{l}\text { Materi yang disampaiakn sudah mencakup, } \\
\text { fakta, konsep, prinsip, dan prosedur. }\end{array}$ & 4 & 5 & 4 \\
\hline 9. & $\begin{array}{l}\text { Penggunaan bahasa pada isi materi sesuai } \\
\text { dengan perkembangan Peserta Didik. }\end{array}$ & 4 & 5 & 4 \\
\hline 10. & $\begin{array}{l}\text { Setiap komponen dalam Modul sudah } \\
\text { menunjukkan adanya inkuiri (merumuskan } \\
\text { masalah, mengajukan hipotesis, mengumpukan } \\
\text { data yang ditemukan, dan membuat } \\
\text { kesimpulan). }\end{array}$ & 4 & 5 & 4 \\
\hline 11. & $\begin{array}{l}\text { Setiap kegiatan atau soal yang terdapat dalam } \\
\text { Modul sudah se suai dengan isi. }\end{array}$ & 4 & 5 & 4 \\
\hline \multicolumn{2}{|r|}{ Jumlah } & 45 & 55 & 46 \\
\hline \multicolumn{2}{|c|}{ Rata-rata } & 4,09 & 5 & 4,1 \\
\hline
\end{tabular}


c. Data Hasil Angket Pengujian Tingkat Keterbacaan oleh Peserta Didik

1. Pengujian Tingkat

Keterbacaan dalam Kelompok Kecil

Pengujian kelompok kecil telah dilaksanakan di MTs Bandar Agung yang berjumlah berjumlah 10 responden siswa kelas VII yang dipilih secara acak. Instrumen yang digunakan dalam uji coba ini adalah angket sebagai sumber data utama. Uji coba kelompok kecil ini dilakukan guna untuk mengetahui tingkat keterbacaan oleh peserta didik. Berikut hasil rekapitulasi data hasil pengujian tingkat keterbacaan oleh peserta didik dalam kelompok kecil sebanyak 10 orang disajikan dalam tabel3.

Tabel 3 Rekapitulasi Data Hasil Pengujian Tingkat Keterbacaan Modul oleh Peserta Didik dalam Kelompok Kecil

\begin{tabular}{|c|c|c|}
\hline No. & Pernyataan & $\begin{array}{c}\sum \\
\text { Penilaian } \\
\text { Peserta Didik }\end{array}$ \\
\hline 1. & $\begin{array}{l}\text { Secara umum Modul menarik dan membuat saya } \\
\text { semangat untuk membacanya. }\end{array}$ & 90 \\
\hline 2. & Penggunaan kata mudah dipahami & 78 \\
\hline 3. & $\begin{array}{l}\text { Pemilihan gambar dalam Modul memudahkan saya } \\
\text { dalam memahami materi. }\end{array}$ & 94 \\
\hline 4. & Petunjuk setiap kegiatan dalam Modul sudah jelas. & 88 \\
\hline 5. & $\begin{array}{l}\text { Informasi yang disediakan menjadikan saya lebih } \\
\text { paham tentang materi interaksi makhluk hidup dengan } \\
\text { lingkungannya. }\end{array}$ & 92 \\
\hline 6. & $\begin{array}{l}\text { Pertanyaan-pertanyaan pada petunjuk praktikum mudah } \\
\text { dipahami dan dijawab. }\end{array}$ & 76 \\
\hline 7. & Ukuran huruf dan jenis huruf terlihat jelas. & 90 \\
\hline 8. & Setiap kegiatan memancing rasa ingin tahu. & 92 \\
\hline 9. & $\begin{array}{l}\text { modul ini mampu mempermudah mempelajari materi } \\
\text { interaksi makhluk hidup dengan lingkungannya. }\end{array}$ & 90 \\
\hline 10. & $\begin{array}{l}\text { Tugas-tugas dalam modul ini mampu membuat materi } \\
\text { interaksi makhluk hidup dengan lingkungannya menjadi } \\
\text { lebih mudah untuk dipahami. }\end{array}$ & 86 \\
\hline \multicolumn{2}{|r|}{ Jumlah } & 876 \\
\hline \multicolumn{2}{|c|}{ Rata-rata } & 87,6 \\
\hline & $\begin{array}{l}\text { Pengujian Tingkat Keterbacaan } \\
\text { dalam Kelompok Besar } \\
\text { Pengujian terhadap modul ini } \\
\text { u untuk mengetahui tingkat }\end{array}$ & $\begin{array}{l}\text { dul dalam } \\
\text { amlah peserta } \\
\text { isi angket ini } \\
\text { siswa, selain } \\
\text { erta didik juga }\end{array}$ \\
\hline
\end{tabular}


diminta memberikan masukan keterbacaan oleh peserta didik terhadap Modul yang telah sebanyak 25 orang disajikan dalam dikembangkan. Hasil rekapitulasi tabel 4.

data hasil pengujian tingkat

Tabel 4 Rekapitulasi Data Hasil Pengujian Tingkat Keterbacaan Modul oleh Peserta Didik dalam Kelompok Besar.

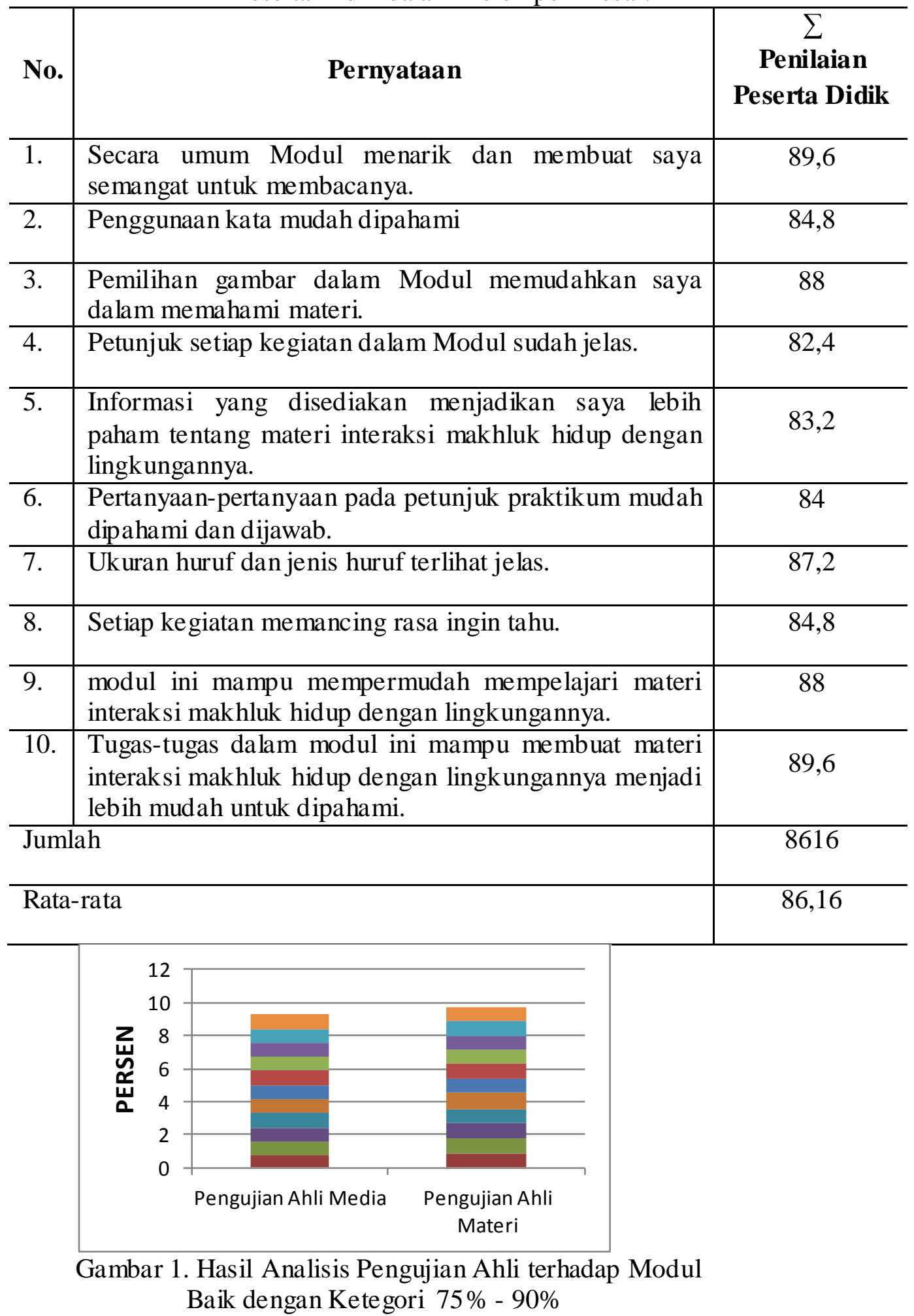


Berdasarkan hasil analisis data Modul tersebut, pengujian yang dilakukan oleh ahli media pembelajaran yang menilai kelayakan tampilan desain Modul menunjukkan persentase penilaian sebesar $84,84 \%$ sehingga produk pengembangan modul pembelajaran berbasis inkuiri tidak perlu direvisi. Pengujian oleh ahli materi yang menilai kelayakan materi dalam Modul yang telah dikembangkan menunjukkan persentase penilaian sebesar 88,47\% sehingga produk Hasil pengujian tingkat keterbacaan modul oleh peserta didik dalam kelompok kecil dan besar dapat dilihat pada tabel 3 dan 4. Hasil rekapitulasi data yang diberikan oleh peserta didik dalam kelompok kecil menunjukkan secara keseluruhan Modul yang telah dikembangkan sudah baik untuk digunakan karena persentase yang diperoleh berdasarkan perhitungan data sebesar 87,6\%. Sedangkan hasil rekapitulasi data yang diberikan oleh peserta didik dalam kelompok besar diperoleh perhitungan data sebesar $86,16 \%$. Sehingga secara keseluruhan Modul yang telah dikembangkan sudah baik untuk digunakan dalam pembelajaran.

Berdasarkan tabel 3 tentang pengujian tingkat keterbacaan peserta didik dalam kelompok kecil dan tabel 4 tentang pengujian tingkat keterbacaan peserta didik dalam kelompok besar menunjukkan bahwa terjadi penurunan pada tingkat keterbacaan dalam kelompok besar. Adapun penurunan persentase penilaian dikarenakan jumlah responden yang semakin banyak dapat mempengaruhi persentase pada uji kelayakan, 1) Tampilan modul, 2) Pemilihan gambar dalam modul, 3) Petunjuk penggunaan modul, 4) Informasi yang berkaitan dengan isi materi, 5) Ukuran huruf dan jenis huruf, 6) Kegiatan dalam modul, 7) Isi materi dalam modul. Hal ini pengembangan modul pembelajaran berbasis inkuiri tidak perlu direvisi.

Kedua hasil pengujian oleh ahli tersebut menurut pendapat Sudjana (dalam Hidayah 2014) masuk dalam kriteria "Baik" dan "Baik". Kriteria tersebut menandakan bahwa Modul yang telah dikembangkan telah dapat digunakan. Persentase penilaian pengujian Modul oleh kedua ahli (media dan materi) dapat disajikan dalam gambar 1 .

dikarenakan pendapat yang beragam dalam menilai modul semakin spesifik, baik dalam tampilan maupun sistematikanya.

\section{KESIMPULAN}

Berdasarkan tahapan-tahapan tersebut maka Modul yang telah dikembangkan sesuai komponenkomponen Modul pada materi interaksi makhluk hidup dengan lingkungannya telah berhasil dan Modul ini baik digunakan dan siap untuk dijadikan sebagai salah satu referensi bahan ajar biologi berbasis inkuiri pada pelajaran IPA biologi materi interaksi makhluk hidup dengan lingkungannya.

\section{SARAN}

a. Modul dapat dimemanfaatkan sebagai proses pembelajaran, guna menunjang kompetensi yang harus dimiliki siswa.

b. Diperlukan penelitian lebih lanjut dengan skala lebih luas guna mengetahui tingkat keefektifan produk modul pembelajaran berbasis inkuiri pada materi interaksi makhluk hidup dengan lingkungannya.

1. Desiminasi

Modul pembelajaran hasil pengembangan diharapkan dapat diterapkan di sekolah-sekolah lain khususnya kelas VII SMP/MTs. 
2. Pengembangan Lanjut Produk Modul pembelajaran berbasis inkuiri ini efektif digunakan dalam pembelajaran. Oleh karena itu, perlu pengembangan lanjut pada meteri-materi yang lain.

\section{DAFTAR PUSTAKA}

Dharma, S. 2008. Penulisan Modul. Jakarta: Direktorat Jenderal Peningkatan Mutu Pendidik dan Tenaga Kependidikan Departemen Pendidikan Nasional. Hlm 1-27.

Elvinawati. 2008. Penerapan Pendekatan Kontekstual dalam Pembelajaran Kimia sebagai Upaya Meningkatkan Aktivitas dan Hasil Belajar Siswa. Jurnal ISSN 1412-3617. Exacta, Vol. VI No. 2. Program Studi Pendidikan Kimia, JPMIPA FKIP UNIB. Hlm 17-22.

Hendarwati, E. 2013. Pengaruh Pemanfaatan Lingkungan sebagai Sumber Belajar melalui Metode Inkuiri terhadap Hasil Belajar Siswa. Jurnal Vol. 2. Fakultas Keguruan dan Ilmu Pendidikan Universitas Muhammadiyah Surabaya. Hlm 59-70

Hidayah, N. H. 2014. Upaya Peningkatan Pemahaman Siswa Terhadap Prinsip Kerja Pneumatik. Jurnal INVOTEC, Volume X, No.1. FPTK Universitas Pendidikan Indonesia. Hlm 47-56.

Novana, Tri. Sajidan. Maridi. 2014. Pengembangan Modul Inkuiri Terbimbing Berbasis Potensi Lokal pada Materi Tumbuhan Lumut (Bryophyta) dan Tumbuhan Paku (Pteridophyta)
Universitas Sebelas Maret Surakarta. Jurnal Inkuiri. ISSN: 2252-7893, Vol 3, No. II. Hlm 108-122.

Purwasari, Y. 2013. Meningkatkan Hasil Belajar IPA tentang Perubahan Kenampakkan Permukaan Bumi dan Benda Langit Melalui Peta Pikiran Pada Anak Kesulitan Belajar. Jurnal Vol 1 No 1 Ilmiah Pendidikan Khusus. HIm 536-548.

Sumiati. A. 2008. Metode Pembelajaran. CV Wacana Prima: Bandung.

Trianto. 2014. Mendesain Model Pembelajaran InovatifProgresif. Jakarta : Kencana Prenada Media Group. 